\title{
A MULTIDIMENSIONAL MARKETING COMMUNICATION MODEL ON SOCIAL MEDIA FOR GLOBAL BRANDS: THE CASE OF COCA-COLA TURKEY
}

\author{
Sarp BAĞCAN \\ İstanbul Gelişim University, Türkiye \\ bagcansarp@gmail.com \\ https://orcid.org/0000-0001-8075-378X \\ Adnan DUYGUN \\ İstanbul Gelişim University, Türkiye \\ aduygun@gelisim.edu.tr \\ https://orcid.org/0000-0003-4026-4054
}

\begin{tabular}{|c|l|}
\hline Atıf & $\begin{array}{l}\text { Bağcan, S. \& Duygun, A. (2022). A Multidimensional Marketing Communication Model on } \\
\text { Social Media for Global Brands: The Case Of Coca-Cola Turkey. The Turkish Online Journal } \\
\text { of Design Art and Communication, 12 (2), 469-482. }\end{array}$ \\
\hline
\end{tabular}

\begin{abstract}
It is possible to say that marketing communication is a part of the marketing mix and plays an important role in interacting between consumers and brands. Recently, social media platforms have become one of the environments used by brands for marketing communication purposes. In this direction, the main purpose of the study is to develop a multidimensional marketing communication model by analyzing the marketing communication efforts of global brands in social media. For this, Coca-Cola, which is at the top of the world brand list of institutions such as Interbrand, BrandZ, Brandfinance, was chosen as an example. For decades, Turkey has been an important base of the brand. Coca-Cola Turkey's Facebook and Twitter accounts were analyzed using content analysis based on the years 2017 and 2020, showing the pre-pandemic and the pandemic period. In this study, a multidimensional marketing communication model has been proposed for various content forms in social media. These dimensions are time, subject, channel, and material. Taecharungroj's (2016) study was used to concretely show the replaceable material dimension of the marketing communication model. The system, created by considering time, subject, channel, and material dimensions, covers a process from content to application. On the other hand, the selected years showed the variation of the dimensions over time. This system will provide an important and holistic contribution to practitioners and similar conveniences for researchers.
\end{abstract}

Keywords: Marketing Communication, Social Media, Global Brands, Multidimensional Model, Content Analysis.

\section{KÜRESEL MARKALAR İÇIN SOSYAL MEDYADA ÇOK BOYUTLU PAZARLAMA İLETISTIMI MODELİ: COCA-COLA TÜRKIYY ÖRNEĞİ}

ÖZ

Pazarlama iletişiminin pazarlama karmasının bir parçası olduğu ve tüketiciler ile markalar arasında etkileşim kurmada önemli bir rol oynadığını söylemek mümkündür. Son dönemlerde sosyal medya platformları, markaların pazarlama iletişimi amaçlı olarak kullandığı ortamlardan biri haline gelmiştir. $\mathrm{Bu}$ doğrultuda ortaya konan çalışmanın temel amacı, küresel markaların sosyal medyadaki pazarlama

Research Article - This article was checked by iThenticate 
iletişimi çabalarını analiz ederek çok boyutlu bir pazarlama iletişimi modeli geliştirmektir. Bunun için Interbrand, BrandZ, Brandfinance gibi kuruluşların dünya marka listesinde üst sıralarda bulunan CocaCola örnek olarak seçilmiştir. On yıllardır Türkiye markanın önemli bir üssüdür. Coca-Cola Türkiye'nin Facebook ve Twitter hesapları, pandemi öncesini ve sürecini de gösterecek şekilde 2017 ve 2020 yılları baz alınarak, içerik analizi kullanılarak incelenmiştir. Bu çalışmada sosyal medyadaki çeşitli içerik formları için çok boyutlu bir pazarlama iletişimi modeli önerilmiştir. Bu boyutlar zaman, konu, kanal ve materyaldir. Pazarlama iletişimi modelinin değiştirilebilir materyal boyutunu somut olarak göstermek için Taecharungroj'un (2016) çalışmasından yararlanılmıştır. Zaman, konu, kanal ve materyal boyutları göz önüne alınarak oluşturulan sistem, içerikten uygulamaya kadar bir süreci kapsamaktadır. Seçilen y1llar ise boyutların zamanla değişimini göstermiştir. Bu sistem; uygulayıcılara önemli, bütüncül bir katkı sunacak, araştırmacılar için de benzer kolaylıklar sağlayacaktır.

Anahtar Kelimeler: Pazarlama İletişimi, Sosyal Medya, Küresel Markalar, Çok Boyutlu Model, İçerik Analizi.

\section{INTRODUCTION}

The number of social media users increases day by day and the rising popularity of sharing almost every subject via social media attracts brand managers to use social media to reach consumers. In this case, a multidimensional communication model will be useful for brand managers to use.

Social media, where people can express their thoughts and ideas, is a platform that can communicate with other people from all over the world (Wirga, et al., 2012: 198; Kathuria, 2016: 228) Social media offers many opportunities for connecting people (Humphreys et al., 2014: 843). It, especially the answering of the questions that people ask, received help with specific instances, an environment that is fun, and interaction between people (Agichtein et al., 2008: 184). Social media consists of words, images, and videos to make people more socialized (Reuben, 2008: 1).

Some popular social media sites or tools are Facebook, YouTube, Twitter, Digg, MySpace, StumbleUpon, Delicious, Scribd, Flickr, etc (Neti, 2011: 2). These tools together in a flatter, more democratic and brings the advantages of possibly more effective communication networks (Hawn, 2009: 365). Especially, Facebook and Twitter are remarkable as social media tools. Facebook was established in 2004. Twitter has grown exponentially since 2008 (Hambrick et al., 2010: 456, 454). Facebook and Twitter, are the two most popular social media platforms (Lalicic et al., 2020: 3; Hussain et al., 2020: 2).

Facebook can connect people for uploading photos, sharing links and videos, and learning more about the people they know and meet. It combines six main components which are "personal profiles, status updates, networks (geographic regions, schools, companies), groups, applications, and fan pages" (Reuben, 2008: 3). Twitter is launched in 2006. It allows people to post their text messages to others (Thomas et al., 2015: 7).

In this study, a model including time, subject, channels, and material (listed as video, photo, and text) basic dimensions has been revealed. The model is also possible to think of the information sharing system as a trigger mechanism. The materials (such as purpose, function) may differ in terms but are ultimately triggered by the system. Taecharungroj's work (2016) was used to concretely show this modifiable material size of the model. When the two models are compared; subject, time, and material dimensions are added. In addition, the content types are detailed with materials which are listed as video, photo, and text.

The content produced by global brands is very well designed and valuable. Likewise, "global brands are those that have global awareness, availability, acceptance, and desirability and are often found under the same name with consistent positioning, image, personality, look, and feel in major markets enabled by standardized and centrally coordinated marketing strategies and programs" (Özsomer et al., 2012: 2).

A global brand is a very suitable choice for observing and modeling social media content. Coca-Cola is a global brand as well as a brand in the fast consumption category. Therefore, promotion-consumption and circulation are more intense than other products and services. It should reach its youth-dominated target audience effectively through social media with a large number of messages.

Research Article - This article was checked by iThenticate 
The relationship of global size and local rootedness in the context of investment shows that Turkey is important for the brand. In the light of the data on social media and the deep-rooted presence of the brand in Turkey, it was decided to choose Coca-Cola Turkey as an example in the study. The multidimensional marketing communication model put forward in the study was reached through these data and multi-dimensional detailed analysis.

In the study, first of all, social media as a marketing communication tool was emphasized. Then, respectively, the titles of methodology - content analysis, the universe and sample, scope and limitations of the study, social media content analysis, and application of methodology: the case of Coca-Cola Turkey are given.

\section{Social Media as A Marketing Communication Tool}

Social media can be used as a channel for many marketing activities such as customer relationship management, customer service, and research, guide generations, sales promotions, advertising, and branding (Ashley and Tuten, 2015: 16). Also, most studies are focused on specific topics such as purchase behavior, customer relationship management, and brand management (Felix et al., 2017: 118).

Nowadays, it can be said that social media mostly can be used as a marketing communication tool. Marketing communications are how firms attempt to inform, persuade, incite, and remind consumers directly or indirectly - about the brands they sell (Keller, 2001: 839).

Social media is an important force in consumer decision making like increasing awareness of consumers, sharing information with others, shaping their opinions and attitudes, purchasing, and finally evaluating their postpurchase experiences (Kwok and Yu, 2012: 1). Social media can change the ways firms communicate with customers as a marketing channel (Ab Hamid et al., 2013: 2). Therefore, social media can be called consumer-generated media (Mangold and Faulds, 2009: 357). Consumers can use social media to generate, edit, and share information about firms, products, and services (Akar and Topçu, 2011: 36).

Customers look for information from social media before deciding on purchasing (Ab Hamid et al., 2013: 2). Especially, social media users trust recommendations from friends (Parsons, 2013: 28). In other words, managers should communicate with consumers to affect their discussions on social media to align these discussions according to the firm's objectives (Al-Mu'ani et al., 2014: 205). Finally, they can estimate the purchase intention of the customer by using social media (Paquette, 2013: 20).

Social media allow people and firms to extend their messages by engaging in two ways. One is communicating with the public and the second is listening to what the public wants from them (Taylor and Kent, 2010: 211). In other words, it is used to help firms be responsible for their actions and to communicate about how their decisions affect other people and firms (DiStaso and Bortree, 2012: 513).

Depending on the explanations so far, it can be concluded that social media enables firms to "share their expertise and knowledge, tap into the wisdom of their consumers enables customers to help customers, engages prospects through customer evangelism" (Neti, 2011:3). Also, the traditional rules of marketing communication were changed by increasing the popularity of social media (Čeněk et al., 2016: 10). The main reason for this, social media is a perfect communicative tool to make a connection directly with customers (Rahman et al., 2016: 87). So, using social media has become a trending marketing communication tool by firms (Ungerman, 2015: 148). This situation can cause the new study area in the field of communication and public relations (Kim and Hammick, 2013: 3).

Facebook is the most attractive social media tool for marketing especially B2C businesses. According to marketing objectives, Facebook gives some opportunities for firms like ads, branding, social plugins, applications, and sponsored stories (Cvijikj and Michahelles, 2013: 846). Favorable customer experiences can make them brand advocates. This causes to increase brand loyalty and referrals and finally a firm's revenues and profits (He et al., 2013: 469).

Research Article - This article was checked by iThenticate 


\section{Methodology - Content Analysis}

Content analysis is widely used in the social sciences (Schwartz and Ungar, 2015: 78). It allows "the gathering of large numbers of qualitative data and transforming them into data of quantitative nature that can be the subject of further statistical analysis" (Čeněk et al., 2016: 12). "Content analysis is a research method that uses a set of procedures to make valid inferences from text" (Macnamara, 2005: 2).

Content analysis is "any technique for making inferences by objectively and systematically identifying specified characteristics of messages" or shortly content analysis is the process of "summarizing, quantitative analysis of messages" (Lai and To, 2015: 140). Likewise, it can be said that the basic method for content analysis is to analyze high-frequency words and draw conclusions depending on the information (Denecke and Nejdl, 2009: 1871).

\section{The Universe and Sample, Scope and Limitations of the Study}

The universe of the study consists of all brands using Facebook and Twitter accounts. However, it is not possible in terms of time and cost to include all of the mentioned brands in the scope of the study. Fast Moving Consumer Goods (FMCG) sector was included in the scope of the study. It is assumed that the FMCG sector, which meets the basic needs of all consumers like beverages, food, and cleaning, will be more inclusive and that brands in the FMCG sector will have more followers on social media.

Since it would not be possible to select all brands in the FMCG sector in terms of numbers, it was decided that it would be appropriate to limit the study to one brand. Depending on the limitations of the study, the FMCG sector and the beverage sector as a sub-sector were chosen within the scope of the study. Coca-Cola Turkey was included in the scope of the study.

In addition to the information in the introduction, it is possible to express the reasons for choosing CocaCola Turkey as follows:

- In 2021, Coca Cola ranks 6th in the Interbrand Best Global Brands 2021 (Interbrand, 2021), 16th in the Kantar BrandZ 2021 Most Valuable Global Brands list (Kantar Brandz, 2021), 4th in the list of Top 25 Strongest Brands according to Brand Finance Global 5002021 (Brand Finance, 2021). Finally, depending on the last report of Brand Finance Global 500 2022, it takes 2nd place in the list of The World's Top 25 Strongest Brands (Brand Finance, 2022). Therefore, Coca-Cola is The World's Largest Nonalcoholic Beverage Company, sold in more than two hundred countries and regions (About: The Coca-Cola Company, 2022).

- Coca-Cola İçecek (CCI) has started production in Turkey in 1964 (CCI, 2022a). CCI is the 5th largest bottler worldwide system according to sales volume (CCI, 2022b).

- The "Brand Footprint" report, published annually by Kantar based on the previous year, reveals the most chosen consumer brands in the world by consumers. It is seen that the Coca-Cola brand took first place in both 2016 and 2019 (Kantar Worldpanel, 2017; Kantar Worldpanel, 2020).

- Choosing Facebook and Twitter as social media platforms can be expressed as follows:

- According to the latest data (February 2022) in the Social Brands list published by Boomsocial every month, Coca-Cola ranks first in the beverage industry, which is a sub-sector of the FMCG, in terms of the number of Facebook fans and Twitter followers. As of February 09, 2022, the number of global Facebook fans is 109,160,850 (Social Brands, Facebook, 2022) and the number of Twitter followers in Turkey is 82,453 (Social Brands, Twitter, 2022).

- In addition, Facebook and Twitter were chosen as platforms with a more comprehensive variety of visual, textual, and audio content compared to Youtube and Instagram.

Another limitation in the study is the time limitation. Firstly, the shares in Coca-Cola Turkey's 2017 Facebook and Twitter accounts were analyzed. It was thought that the time limit in the study would also be useful for the exchange and observation of the subject, content, and materials. In order to understand what these changes are or could be, 3 years later, in other words, 2020 was included in the study. The

Submit Date: 13.01.2022, Acceptance Date: 26.02.2022, DOI NO: 10.7456/11202100/017

Research Article - This article was checked by iThenticate

Copyright (C) The Turkish Online Journal of Design, Art and Communication 
year 2020 has also been a year in which the effects of the Covid-19 pandemic began to be seen. 2021 has been a year in which the effects of Covid-19 continued. For this reason, 2020, the year the Covid19 pandemic started, was thought to be more distinctive in terms of examination, and 2020 was included in the scope of the study as the year decided at the beginning of the study.

Considering that social media environments are changing very dynamically and rapidly, the shares of 2017 were examined between January 10-January 31, 2018, and the shares of 2020 were examined between January 10-January 31, 2021.

\section{Social Media Content Analysis}

Content analysis on social media can use by firms to develop marketing strategies. They can decide the popularity of their products and sentiment or attitude analysis can be used to study the public response about the firm products (Wirga et al., 2012: 202).

Table 1 exhibits some studies of social media content analyzes. Different dimensions are used by different authors. As stated earlier in this study, the model was developed based on the strategy model which was put forward by Taecharungroj in 2016, on social media marketing communication.

Table 1. Some Examples of Social Media Content Analyzes

\begin{tabular}{|c|c|}
\hline Author/Authors & Dimensions \\
\hline Waters and Lo (2012: 307) & $\begin{array}{ll}- & \text { Disclosure } \\
- & \text { Individual } \\
- & \text { Information Dissemination } \\
- & \text { Involvement }\end{array}$ \\
\hline Shen and Bissell (2013: 630) & $\begin{array}{ll}\text { - } & \text { The frequency of communication with clients } \\
\text { - } & \text { The types of engagement their consumers } \\
- & \text { The degree of connectivity with fans }\end{array}$ \\
\hline Chew and Eysenbach (2010: 2) & $\begin{array}{ll}- & \text { Resource } \\
- & \text { Personal experience } \\
- & \text { Personal opinion and interest } \\
- & \text { Jokes/parody } \\
- & \text { Marketing } \\
- & \text { Spam } \\
\end{array}$ \\
\hline Hambrick et al. (2010: 460) & $\begin{array}{ll}\text { - } & \text { Interactivity } \\
- & \text { Diversion } \\
- & \text { Information sharing } \\
- & \text { Content } \\
- & \text { Fanship } \\
- & \text { Promotional } \\
\end{array}$ \\
\hline Rahman et al. (2016: 90); Rahman et al. (2017: 90) & $\begin{array}{ll}- & \text { Only image post } \\
- & \text { Image with detail post } \\
- & \text { Feature video } \\
- & \text { Entertaining video } \\
\end{array}$ \\
\hline Taecharungroj (2016: 8) & $\begin{array}{ll}- & \text { Information-sharing content } \\
- & \text { Emotion-evoking content } \\
- & \text { Action-inducing content } \\
\end{array}$ \\
\hline Richards and Friess (2015: 189-190) & $\begin{array}{ll}- & \text { Nature appreciation } \\
- & \text { Landscape } \\
- & \text { Social recreation } \\
- & \text { Fishing creation } \\
- & \text { History } \\
- & \text { Research } \\
- & \text { Infrastructure appreciation } \\
- & \text { Other }\end{array}$ \\
\hline
\end{tabular}

In this study by Taecharungroj (2016) was used for the coding scale. The contents were analyzed under three types which are Information-sharing content, Emotion-evoking content, and Action-inducing content (Taecharungroj, 2016: 8). Information sharing is the first content type. It is used to communicate valuable information to followers who maybe can get benefits by receiving information (Taecharungroj, 2016: 7-8). The second content type is emotion-evoking. The main purpose of it seems to be to evoke

Research Article - This article was checked by iThenticate 
positive emotions in followers (Taecharungroj, 2016: 9). Finally, action-inducing content is the last content type. It attempts to persuade followers to take the desired action (Taecharungroj, 2016: 9).

\section{Application of Methodology: The Case of Coca-Cola Turkey}

Offering methodology for social media content analysis (Lai and To, 2015: 141-144; Kathuria, 2016: 229-230):

- Definition of goal and scope

- Data collection

- Data transformation

- Interpretation of results

\section{Definition of goal and scope}

The main goal of this study is to analyze the marketing communication efforts of brands in social media by developing a multi-dimensional marketing communication model. Coca-Cola is chosen for this purpose.

Coca-Cola Turkey's Facebook and Twitter channels were examined. A parallel review of Facebook and Twitter channels was made to see if this system can be managed synchronously.

\section{Data collection}

The data was gathered from Coca-Cola's Facebook and Twitter channels between the dates January 1st of 2017 and December 31st of 2017 and January 1st of 2020 and December 31st of 2020. Three types of content were used. The main categories of three types of content are "information-sharing content", "emotion-evoking content", and "action-inducing content" (Taecharungroj, 2016: 8).

\section{Data transformation}

The content discussed in the study was evaluated based on the impact-sharing-oriented approach by adding a subject, time, and material dimensions by using Facebook and Twitter channels. Table 2 displays the subject dimension of Coca-Cola Turkey Facebook shares and Tweets in 2017 and 2020.

Table 2. Coca-Cola Turkey Facebook Shares and Tweets in 2017 and 2020 According to Subject Dimension

\begin{tabular}{|c|c|c|}
\hline 2017 & \multirow{2}{*}{ Facebook } & \multirow{2}{*}{ Twitter } \\
\hline Subjects & & \\
\hline Social Relations and Coca-Cola & 9 & 12 \\
\hline Football and Coca-Cola & 29 & 23 \\
\hline Food and Coca-Cola & 30 & 28 \\
\hline $\begin{array}{l}\text { Marketing and Special Event Activities - } \\
\text { Coca-Cola }\end{array}$ & 60 & 51 \\
\hline Total & 128 & 114 \\
\hline 2020 & \multirow{2}{*}{ Facebook } & \multirow{2}{*}{ Twitter } \\
\hline $\begin{array}{l}\text { Subjects } \\
\end{array}$ & & \\
\hline $\begin{array}{l}\text { Corporate Social Responsibility (CSR) } \\
\text { about Covid-19 and Coca-Cola }\end{array}$ & 13 & 13 \\
\hline Tv Series and Coca-Cola & 29 & 42 \\
\hline E-Game and Coca-Cola & 27 & 53 \\
\hline $\begin{array}{l}\text { Marketing and Special Event Activities - } \\
\text { Coca-Cola }\end{array}$ & 27 & 25 \\
\hline Social Relations and Coca-Cola & 3 & 7 \\
\hline Food and Coca-Cola & 4 & 2 \\
\hline Total & 103 & 142 \\
\hline
\end{tabular}

When the 2020 subjects in Table 2 are examined, it is seen that the subjects discussed have changed when 2017 is compared. The impact of the Covid-19 pandemic is seen in 2020. Social relations were 
restricted due to the pandemic effect and football matches could not be played for a certain period. Football matches are still played without an audience. During this period, as people spent more time at home, they focused on activities that can be done at homes such as watching TV series and playing games. Again, during the pandemic era, the e-game tournament also came to the fore in shares. In the context of Covid-19, the brand has turned to Corporate Social Responsibility (CSR) activities in order to support both the health and the food and beverage sector with which it is connected, through its foundation. This situation is also reflected in Coca-Cola's shares on Facebook and Twitter channels.

Table 3. Content-Type of Facebook Shares According to Months in 2017 and 2020

\begin{tabular}{|c|c|c|c|c|c|c|c|c|}
\hline \multirow[b]{3}{*}{ Months } & \multicolumn{8}{|c|}{ Content-Type } \\
\hline & \multicolumn{4}{|c|}{2017} & \multicolumn{4}{|c|}{2020} \\
\hline & $\begin{array}{c}\text { Information- } \\
\text { Sharing } \\
\text { (IS) }\end{array}$ & $\begin{array}{l}\text { Emotion } \\
\text {-Evoking } \\
\text { (EE) }\end{array}$ & $\begin{array}{l}\text { Action- } \\
\text { Inducing } \\
\text { (AI) }\end{array}$ & Total & $\begin{array}{l}\text { Information } \\
\text {-Sharing } \\
\text { (IS) }\end{array}$ & $\begin{array}{l}\text { Emotion } \\
\text {-Evoking } \\
\text { (EE) }\end{array}$ & $\begin{array}{l}\text { Action- } \\
\text { Inducing } \\
\text { (AI) }\end{array}$ & Total \\
\hline January & 5 & 2 & 3 & $10(7.8 \%)$ & 4 & - & - & $4(3.9 \%)$ \\
\hline February & 10 & 3 & 4 & $17(13.3 \%)$ & 5 & - & 9 & $14(13.6 \%)$ \\
\hline March & 10 & 3 & 4 & $17(13.3 \%)$ & 9 & - & 3 & $12(11.7 \%)$ \\
\hline April & 5 & 5 & 1 & $11(8.6 \%)$ & 7 & - & - & $7(6.8 \%)$ \\
\hline May & 10 & 2 & 3 & $15(11.7 \%)$ & 12 & 1 & 6 & $19(18.4 \%)$ \\
\hline June & 4 & 3 & 0 & $7(5.5 \%)$ & 1 & - & 2 & $3(2.9 \%)$ \\
\hline July & 6 & 2 & 0 & $8(6.2 \%)$ & - & - & - & $0(0.0 \%)$ \\
\hline August & 3 & 1 & 2 & $6(4.7 \%)$ & - & - & - & $0(0.0 \%)$ \\
\hline September & 5 & 4 & 0 & $9(7.0 \%)$ & - & - & - & $0(0.0 \%)$ \\
\hline October & 5 & 0 & 7 & $12(9.4 \%)$ & 14 & - & - & $14(13.6 \%)$ \\
\hline November & 6 & 5 & 2 & $13(10.2 \%)$ & 16 & - & - & $16(15.5 \%)$ \\
\hline December & 2 & 0 & 1 & $3(2.3 \%)$ & 10 & - & 4 & $14(13.6 \%)$ \\
\hline Total & $\begin{array}{c}71 \\
(55.5 \%) \\
\end{array}$ & $\begin{array}{c}30 \\
(23.4 \%) \\
\end{array}$ & $\begin{array}{c}27 \\
(21.1 \%) \\
\end{array}$ & $\begin{array}{c}128 \\
(100.0 \%) \\
\end{array}$ & $\begin{array}{c}78 \\
(75.7 \%) \\
\end{array}$ & $\begin{array}{c}1 \\
(1.0 \%)\end{array}$ & $\begin{array}{c}24 \\
(23.3 \%) \\
\end{array}$ & $\begin{array}{c}103 \\
(100.0 \%)\end{array}$ \\
\hline
\end{tabular}

When compared in terms of content according to Table 3, the number of Facebook shares decreased in 2020 compared to 2017. This becomes clearer, especially in June, July, August, and September 2020. It is thought that it was difficult to produce content in this period when mass sports competitions such as football could not be sustained as before due to the isolation rules brought by the pandemic. However, the football and Coca-Cola subject continued, albeit at a lower level.

Table 4. Content-Type of Tweets According to Months in 2017 and 2020

\begin{tabular}{|c|c|c|c|c|c|c|c|c|}
\hline \multirow[b]{3}{*}{ Months } & \multicolumn{8}{|c|}{ Content-Type } \\
\hline & \multicolumn{4}{|c|}{2017} & \multicolumn{4}{|c|}{2020} \\
\hline & $\begin{array}{c}\text { Information- } \\
\text { Sharing } \\
\text { (IS) }\end{array}$ & $\begin{array}{c}\text { Emotion } \\
\text {-Evoking } \\
\text { (EE) }\end{array}$ & $\begin{array}{l}\text { Action- } \\
\text { Inducing } \\
\text { (AI) }\end{array}$ & Total & $\begin{array}{c}\text { Information } \\
\text {-Sharing } \\
\text { (IS) }\end{array}$ & $\begin{array}{c}\text { Emotion } \\
\text {-Evoking } \\
\text { (EE) }\end{array}$ & $\begin{array}{l}\text { Action- } \\
\text { Inducing } \\
\text { (AI) }\end{array}$ & Total \\
\hline January & 4 & 8 & 0 & $12(10.5 \%)$ & 4 & - & - & $4(2.8 \%)$ \\
\hline February & 11 & 3 & 3 & $17(14.9 \%)$ & 4 & - & 4 & $8(5.6 \%)$ \\
\hline March & 9 & 5 & 3 & $17(14.9 \%)$ & 12 & - & 3 & $15(10.6 \%)$ \\
\hline April & 4 & 5 & 0 & $9(7.9 \%)$ & 7 & - & - & $7(4.9 \%)$ \\
\hline May & 10 & 2 & 4 & $16(14.1 \%)$ & 12 & 13 & 10 & $35(24.7 \%)$ \\
\hline June & 4 & 3 & 1 & $8(7.0 \%)$ & 2 & - & 9 & $11(7.7 \%)$ \\
\hline July & 3 & 2 & 0 & $5(4.4 \%)$ & - & - & - & $0(0.0 \%)$ \\
\hline August & 2 & 1 & 1 & $4(3.5 \%)$ & - & - & - & $0(0.0 \%)$ \\
\hline September & 4 & 4 & 0 & $8(7.0 \%)$ & 11 & 1 & 4 & $16(11.3 \%)$ \\
\hline October & 5 & 0 & 7 & $12(10.5 \%)$ & 17 & - & - & $17(12.0 \%)$ \\
\hline November & 2 & 1 & 1 & $4(3.5 \%)$ & 6 & - & - & $6(4.2 \%)$ \\
\hline December & 2 & 0 & 0 & $2(1.8 \%)$ & 12 & 1 & 10 & $23(16.2 \%)$ \\
\hline Total & $\begin{array}{c}60 \\
(52.6 \%)\end{array}$ & $\begin{array}{c}34 \\
(29.8 \%)\end{array}$ & $\begin{array}{c}20 \\
(17.6 \%)\end{array}$ & $\begin{array}{c}114 \\
(100.0 \%)\end{array}$ & $\begin{array}{c}87 \\
(61.3 \%) \\
\end{array}$ & $\begin{array}{c}15 \\
(10.5 \%)\end{array}$ & $\begin{array}{c}40 \\
(28.2 \%)\end{array}$ & $\begin{array}{c}142 \\
(100.0 \%)\end{array}$ \\
\hline
\end{tabular}

Depending on the figures in Table 4, it is seen that the number of Tweets on Twitter increased compared to Facebook in 2020. July and August 2020 data are similar to Facebook. Coca-Cola used Twitter more

Submit Date: 13.01.2022, Acceptance Date: 26.02.2022, DOI NO: 10.7456/11202100/017

Research Article - This article was checked by iThenticate

Copyright (C) The Turkish Online Journal of Design, Art and Communication 
intensely due to the Ramadan month in May 2020, the opening of schools and the increase in the time spent at home in September 2020, and the effect of New Year in December 2020. Therefore, it is possible to attribute the increase of Tweets to this.

Table 5. Materials of Facebook Shares According to Months in 2017 and 2020

\begin{tabular}{|c|c|c|c|c|c|c|c|c|}
\hline \multirow{3}{*}{ Months } & \multicolumn{8}{|c|}{ Materials } \\
\hline & \multicolumn{4}{|c|}{2017} & \multicolumn{4}{|c|}{2020} \\
\hline & $\begin{array}{l}\text { Video } \\
\text { (V) }\end{array}$ & $\begin{array}{l}\text { Photo } \\
\text { (P) }\end{array}$ & $\begin{array}{c}\text { Text } \\
\text { (T) }\end{array}$ & Total & $\begin{array}{l}\text { Video } \\
\text { (V) }\end{array}$ & $\begin{array}{l}\text { Photo } \\
\text { (P) }\end{array}$ & $\begin{array}{c}\text { Text } \\
\text { (T) }\end{array}$ & Total \\
\hline January & 6 & 4 & - & $10(7.8 \%)$ & 2 & 2 & - & $4(3.9 \%)$ \\
\hline February & 4 & 13 & - & $17(13.3 \%)$ & 14 & - & - & $14(13.6 \%)$ \\
\hline March & 6 & 11 & - & $17(13.3 \%)$ & 12 & - & - & $12(11.7 \%)$ \\
\hline April & 7 & 4 & - & $11(8.6 \%)$ & 3 & 4 & - & $7(6.8 \%)$ \\
\hline May & 4 & 11 & - & $15(11.7 \%)$ & 10 & 6 & 3 & $19(18.4 \%)$ \\
\hline June & 3 & 4 & - & $7(5.5 \%)$ & 2 & 1 & - & $3(2.9 \%)$ \\
\hline July & 4 & 3 & 1 & $8(6.2 \%)$ & - & - & - & $0(0.0 \%)$ \\
\hline August & 2 & 4 & - & $6(4.7 \%)$ & - & - & - & $0(0.0 \%)$ \\
\hline September & 9 & - & - & $9(7.0 \%)$ & - & - & - & $0(0.0 \%)$ \\
\hline October & 9 & 3 & - & $12(9.4 \%)$ & 14 & - & - & $14(13.6 \%)$ \\
\hline November & 8 & 5 & - & $13(10.2 \%)$ & 14 & 1 & 1 & $16(15.5 \%)$ \\
\hline December & 3 & - & - & $3(2.3 \%)$ & 10 & 4 & - & $14(13.6 \%)$ \\
\hline Total & $\begin{array}{c}65 \\
(50.8 \%) \\
\end{array}$ & $\begin{array}{c}62 \\
(48.4 \%) \\
\end{array}$ & $\begin{array}{c}1 \\
(0.8 \%)\end{array}$ & $\begin{array}{c}128 \\
(100.0 \%)\end{array}$ & $\begin{array}{c}81 \\
(78.6 \%) \\
\end{array}$ & $\begin{array}{c}18 \\
(17.5 \%)\end{array}$ & $\begin{array}{c}4 \\
(3.9 \%)\end{array}$ & $\begin{array}{c}103 \\
(100.0 \%)\end{array}$ \\
\hline
\end{tabular}

The use of the material in Table 5 is also compatible with the content type in Facebook shares. When 2017 and 2020 are compared; It is seen that photo sharing has decreased considerably in 2020. This situation caused the total share to decrease in 2020 . However, it turns out that video sharing is relatively higher in 2020.

Table 6. Materials of Tweets According to Months in 2017 and 2020

\begin{tabular}{|c|c|c|c|c|c|c|c|c|}
\hline \multirow{3}{*}{ Months } & \multicolumn{8}{|c|}{ Materials } \\
\hline & \multicolumn{4}{|c|}{2017} & \multicolumn{4}{|c|}{2020} \\
\hline & $\begin{array}{l}\text { Video } \\
\text { (V) }\end{array}$ & $\begin{array}{l}\text { Photo } \\
\text { (P) }\end{array}$ & $\begin{array}{l}\text { Text } \\
\text { (T) }\end{array}$ & Total & $\begin{array}{l}\text { Video } \\
\text { (V) }\end{array}$ & $\begin{array}{l}\text { Photo } \\
\text { (P) }\end{array}$ & $\begin{array}{c}\text { Text } \\
\text { (T) }\end{array}$ & Total \\
\hline January & 8 & 4 & - & $12(10.5 \%)$ & 2 & 2 & - & $4(2.8 \%)$ \\
\hline February & 11 & 6 & - & $17(14.9 \%)$ & 6 & 2 & - & $8(5.6 \%)$ \\
\hline March & 6 & 11 & - & $17(14.9 \%)$ & 14 & 1 & - & $15(10.6 \%)$ \\
\hline April & 7 & 2 & - & $9(7.9 \%)$ & 5 & 2 & - & $7(4.9 \%)$ \\
\hline May & 5 & 11 & - & $16(14.1 \%)$ & 10 & 23 & 2 & $35(24.7 \%)$ \\
\hline June & 3 & 4 & 1 & $8(7.0 \%)$ & 7 & 1 & 3 & $11(7.7 \%)$ \\
\hline July & 3 & 2 & - & $5(4.4 \%)$ & - & - & - & $0(0.0 \%)$ \\
\hline August & 1 & 3 & - & $4(3.5 \%)$ & - & - & - & $0(0.0 \%)$ \\
\hline September & 7 & 1 & - & $8(7.0 \%)$ & 9 & 4 & 3 & $16(11.3 \%)$ \\
\hline October & 9 & 3 & - & $12(10.5 \%)$ & 17 & - & - & $17(12.0 \%)$ \\
\hline November & 3 & 1 & - & $4(3.5 \%)$ & 6 & - & - & $6(4.2 \%)$ \\
\hline December & 2 & - & - & $2(1.8 \%)$ & 12 & 2 & 9 & $23(16.2 \%)$ \\
\hline Total & $\begin{array}{c}65 \\
(57.0 \%)\end{array}$ & $\begin{array}{c}48 \\
(42.1 \%)\end{array}$ & $\begin{array}{c}1 \\
(0.9 \%)\end{array}$ & $\begin{array}{c}114 \\
(100.0 \%)\end{array}$ & $\begin{array}{c}88 \\
(62.0 \%) \\
\end{array}$ & $\begin{array}{c}37 \\
(26.0 \%) \\
\end{array}$ & $\begin{array}{c}17 \\
(12.0 \%)\end{array}$ & $\begin{array}{c}142 \\
(100.0 \%)\end{array}$ \\
\hline
\end{tabular}

The use of the material in Table 6 is also compatible with the content on Twitter, similar to Facebook. Unlike Facebook, the increase in the number of Tweets in text form is striking. Additionally, while video sharing increased, photo sharing decreased.

\section{Interpretation of results}

In this section, a multidimensional marketing communication model has been developed for brands to be used in social media based on the results obtained. Figure 1 shows the framework or model for Starbucks' marketing communications strategy on Twitter that is depending on Taecharungroj's model. This indicates brand and customer interactions on Twitter (Taecharungroj, 2016). 


\section{TWITTER}

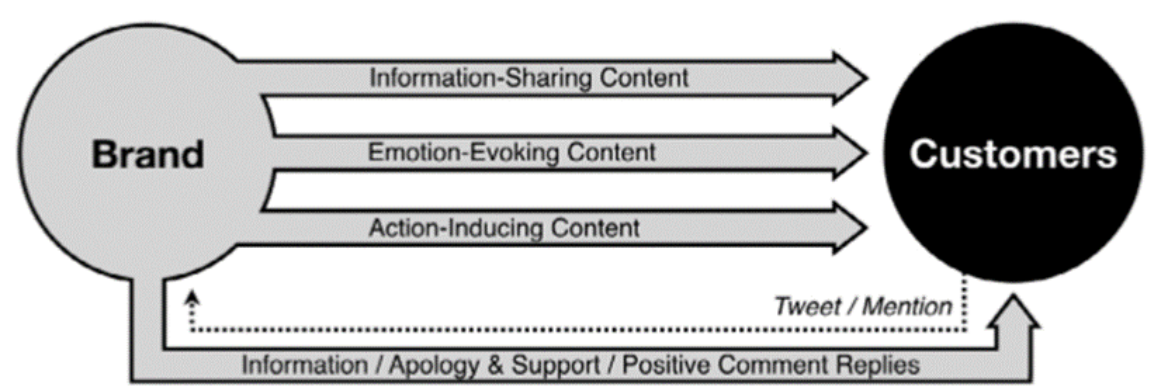

Figure 1. Framework for Starbucks' marketing communications strategy on Twitter

Source: (Taecharungroj, 2016: 15)

The developed model in this study can be seen in Figure 2. When the two models seen in Figure 1 and Figure 2 are compared; it is possible to see that subject, time, and material dimensions are added in Figure 2. In addition, the content types are detailed with materials in Figure 2. The materials are listed as video, photo, and text.

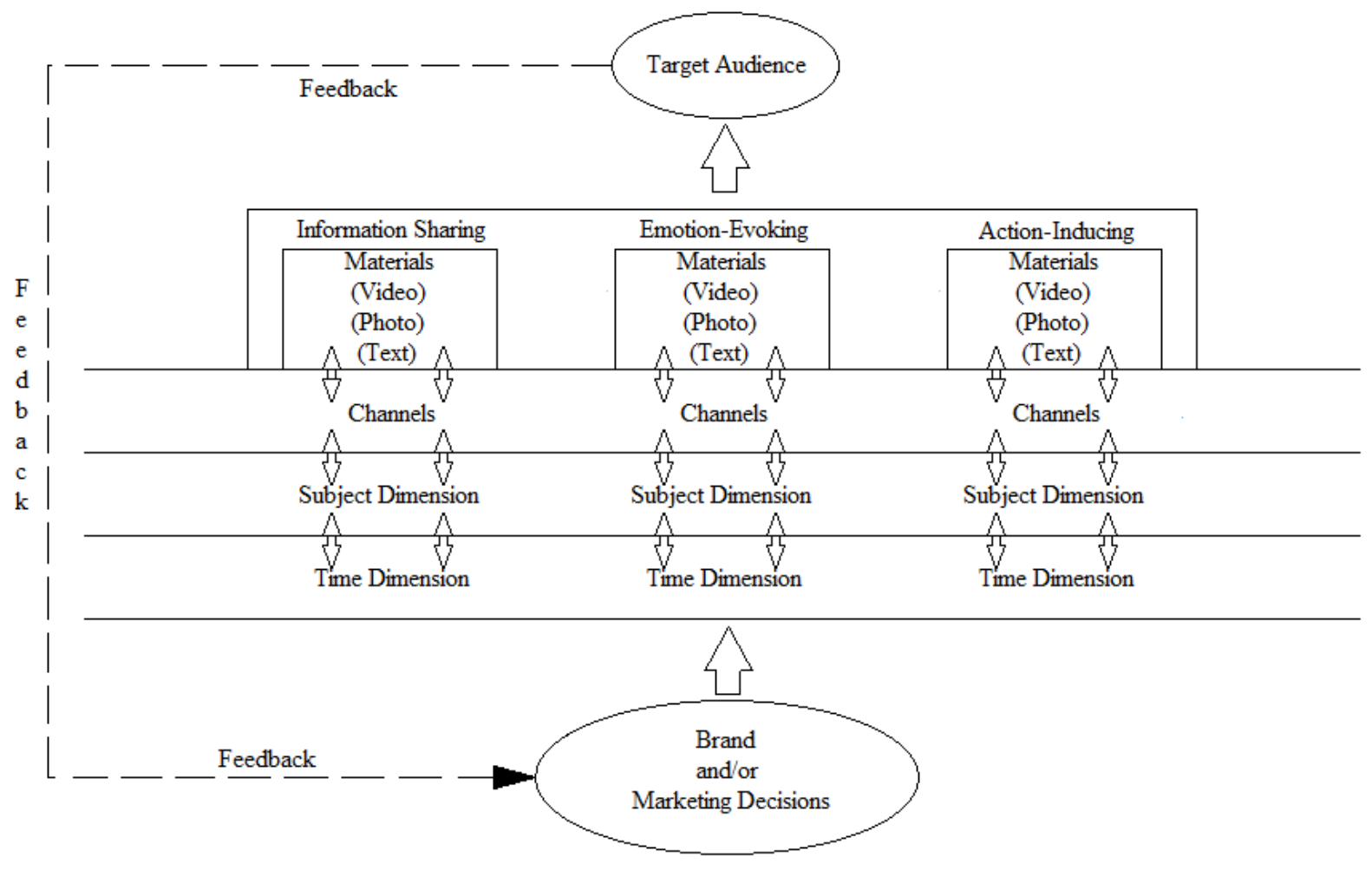

Figure 2. The Developed Multidimensional Marketing Communication Model on Social Media for Global Brands

The developed model consists of the combination of the subject - time - channel (Facebook, Twitter) material and message - mass interaction dimensions that were originally introduced in the data collection section. The purpose of the model is to create a social media marketing communication model that can be programmed (e.g. 1 year, and subdivided within itself, such as quarters) and managed for a brand through the time dimension. The time dimension in the model shows that the model is dynamic and that running it is also process management. Since marketing communication depends on direct marketing 
and brand decisions, the model includes marketing and brand decisions as the main starting and impact points.

When the basic dimension of the model is examined, its effect on the subject has also been revealed. The subject dimension is seen to be related to the time dimension. For example, it has been found that the one-year process is appropriate for obtaining a clear view of showing fluctuations and seasonality (considering the brand's shares regarding the seasons, football agenda, competition programsponsorship of football-cinema issues, youth campaigns in 2017, Covid-19, CSR activities, tv series, egame tournament in 2020). The periodicity here is not only about the season, but also about the brand's agendas, such as the football season and the process of continuing youth campaigns. To show this relationship, a two-way arrow sign was used in terms of time and subject dimensions. Because sometimes the season/time determines the subject, and sometimes the brand does not regulate but adds it to its agenda as a sponsor, football-film-competition sponsorships that are created in this way by the agenda (hence sharing) are included in the communication calendar of the brand and also affect their fluctuations. The examples showed this relationship dimension of the model. Using time dimension is sometimes related to subject dimensions also. Advertising, sponsorship, etc. in traditional channels such as TV illustrates a holistic marketing communication strategy including social media. That is why there is another feedback line on the left that belongs to traditional media although our focus is social media.

When the shares on the time dimension are categorized, the brand basically shares in four subject categories in 2017. These topics are "Social Relations and Coca-Cola", "Football and Coca-Cola", "Food and Coca-Cola", and finally "Marketing and Special Event Activities". Topics are essential in creating the image of the brand and in clarifying the target audience. The issues were associated with the brand's socialization, football, and food, and the target audience was mostly young people when the shares were analyzed. "Marketing and Special Event Activities" are mostly related to sponsorships and youth campaigns of the brand.

In 2020 the subjects are "Corporate Social Responsibility (CSR) about Covid-19 and Coca-Cola", "Tv Series and Coca-Cola", "E-Game and Coca-Cola", "Marketing and Special Event Activities - CocaCola", "Social Relations and Coca-Cola" and "Food and Coca-Cola". The subjects are TV series and Coca-Cola, E-game Tournament and Coca Cola (directly targeting young people) have risen, Food and Coca-Cola maintained in a low profile. As the reason for these, social isolation brought by Covid-19 as a must and cancellation of outdoor social events should be considered as effects.

This dimension of the model (considering the bidirectional link arrow) shows in terms of management how the agenda changes as a process and when. It also shows the outline of the brand image and how the target audience can be crystallized. Of course, in the process of managing this model, the brand that will use the model should clarify its brand and marketing decisions before.

The bidirectional arrow between the subject dimension and the channel sometimes expresses the effect of the subject and sometimes the media channel (e.g. social media in focus in the study). As a matter of fact, while the subject categories of the brand generally go the same as the general lines on Facebook and Twitter. In 2020, the e-game tournament and tv series also have targeted youth. This is also checked by two different years' data. At this point, the subject determines the channel regarding the target audience and the channels it prefers. The media channel can also influence the issue. Because, apart from the traditional media, special campaigns such as social media and special to it, etc., it can be made. Considering the model, it is seen that it is important to consider the channel-subject relationship in two ways in social media management in order to increase the interaction and diversity appropriate for the purpose and target audience. While the topics can change the channel selection, the channels can also influence the topics.

It is seen that the channels are shared in accordance with IS (Information-sharing content), EE (Emotionevoking content), and AI (Action-inducing content) message-mass interactions. This is the final stage in

Submit Date: 13.01.2022, Acceptance Date: 26.02.2022, DOI NO: 10.7456/11202100/017

Research Article - This article was checked by iThenticate 
the model between the channel and the audience, and the final stage in which the content turns into the material and the type of targeted interaction. It is seen that visual sharing for the young audience is dominant. At this stage, most of the photos are still in gif format and animated in 2017. In 2020, the number of photos decreased and videos increased. This visually shows that animated content is preferred. Therefore, it was observed that the targeted interaction was mostly tried to be provided by mobile and visual sharing. This situation not only represents elements such as movement, energy, which are part of the brand image but also addresses the perceptions of young people who are the target audience. While the type of material (e.g. video, gif) affects channel selection, the sharing structure in the channel determines the material. This refers to the bidirectional arrow between the channel and the material. Visual, written material types can be found both in traditional media (except gif etc.) and on the internet and social media.

As given in the previous sections, IS-type sharing is informative, relationship building, and guiding about the four main topics of the brand. It is understood that EE-type shares are designed to leave an emotional depth and impact on the way that IS-type shares open or support it. But, the decrease in social sponsorships such as outdoor sponsorships/events and football in 2020 has also decreased EE type of shares.

On the other hand, it was determined that AI type sharing was used especially to connect these issues to sales development. When and what type of material and content type the brand's annual agenda is given, it is seen. The informative / guiding content type, intertwined with the material type, also interacts with the structure and mass of the channel. This is what shows the bidirectional arrow between the content and the channel. The feedback line on the left shows the internet and social media.

In total, it has been determined that the topics that are interactive with the time dimension, the channels related to the topics, the sharing types related to the channels (in terms of material and effect) are found as a whole/system. When viewed from the reverse, it is seen that everything from the most extreme sharing material and the targeted effect to the channel, subject, and time depends on the initial marketing and brand decisions. In this way, the frame and starting point of the model has emerged. It has been observed that global issues such as Covid-19 can also affect the marketing communication of the brand. From this point of view, the model has been put forward as a model with the four dimensions mentioned in the social media management from the beginning point to the end in terms of marketing communication of a brand. The model's feedback line should also be considered with these dimensions, it is important in revising or developing decisions.

It has been seen that global issues can also be handled in terms of marketing communication and content. The current model should be considered in conjunction with the macro external conditions surrounding the institution.

Everything is in a set, from decisions to timing and issues, from channels to material, and the desired effects on the target audience. The decisions have the opportunity to be transferred to the target audience with a system that has significant internal consistency and continuity.

\section{REFERENCES}

About: The Coca-Cola Company (2022). Company profile, the world's largest nonalcoholic beverage company, https://investors.coca-colacompany.com/about. Access Date: 15.02.2022.

Ab Hamid, N. R., Md Akhir, R. and Cheng, A. Y. (2013). Social media: An emerging dimension of marketing communication. Journal of Management and Marketing Research. https://www.aabri.com/manuscripts/121420.pdf. Access Date: 15.10.2016.

Agichtein, E., Castillo, C., Donato, D., Gionis, A. and Mishne, G. (2008). Finding high-quality content in social media, WSDM’08, February 11-12, 2008, Palo Alto, California, USA: 183-193. 
Akar, E. and Topçu, B. (2011). An examination of the factors influencing consumers' attitudes toward social media marketing. Journal of Internet Commerce, 10: 35-67.

Al-Mu'ani, L., Saydam, S. and Çalicioğlu, C. (2014). Facebook as a marketing communications tool Facebook official pages content analysis for Jordanian Telecommunications Companies in the mobile operators sector. International Journal of Business and Social Science, 5(4), Special Issue: 205-211.

Ashley, C. and Tuten, T. (2015). Creative strategies in social media marketing: An exploratory study of branded social content and consumer engagement. Psychology and Marketing, 32(1): 15-27.

Brand Finance (2021). Global 500 2021, the annual report on the most valuable and strongest global brands. https://brandirectory.com/download-report/brand-finance-global-500-2021-preview.pdf.

Access Date: 15.02.2022.

Brand Finance (2022). Global 500 2022, the annual report on the world's most valuable and strongest brands. https://brandirectory.com/download-report/brand-finance-global-500-2022-preview.pdf. Access Date: 15.02.2022.

CCI (2022a). Operations in Turkey. https://www.cci.com.tr/en/our-company/our-geography/turkey. Access Date: 14.02.2022.

CCI (2022b). Success stories. https://www.invest.gov.tr/en/whyturkey/successstories/pages/cocacola.aspx. Access Date: 14.02.2022.

Čeněk, J., Smolík, J. and Svatošová, V. (2016). Marketing on social networks: Content analysis of Facebook profiles of selected Czech e-shops. Trends Economics and Management, 26(2): 9-20.

Chew, C. and Eysenbach, G. (2010). Pandemics in the Age of Twitter: Content analysis of tweets during the 2009 H1N1 outbreak. PLoS ONE, 5(11): 1-13.

Cvijikj, I. P. and Michahelles, F. (2013). Online engagement factors on Facebook brand pages. Social Network Analysis and Mining, 3: 843-861.

Denecke, K. and Nejdl, W. (2009). How valuable is medical social media data? Content analysis of the medical web. Information Sciences, 179: 1870-1880.

DiStaso, M. W. and Bortree, D. S. (2012). Multi-method analysis of transparency in social media practices: Survey, interviews and content analysis. Public Relations Review, 38: 511-514.

Felix, R., Rauschnabel, P. A. and Hinsch, C. (2017). Elements of strategic social media marketing: A holistic framework. Journal of Business Research, 70: 118-126.

Hambrick, M. E., Simmons, J. M., Greenhalgh, G. P. and Greenwell, T. C. (2010). Understanding professional athletes' use of Twitter: A content analysis of athlete tweets. International Journal of Sport Communication, 3: 454-471.

Hawn, C. (2009). Take two aspirin and tweet me in the morning: How Twitter, Facebook, and other social media are reshaping health care. Health Affairs, 28(2): 361-368.

He, W., Zha, S. and Li, L. (2013). Social media competitive analysis and text mining: A case study in the pizza industry. International Journal of Information Management, 33: 464-472.

Hussain, A., Tahir, A., Hussain, Z., Sheikh, Z., Gogate, M., Dashtipour, K., Ali, A. and Sheikh, A. (2020). Artificial intelligence-enabled analysis of UK and US public attitudes on Facebook and Twitter towards COVID-19 vaccinations. medRxiv.

https://www.medrxiv.org/content/10.1101/2020.12.08.20246231v1.full.pdf. Access Date: 11.01.2021.

Submit Date: 13.01.2022, Acceptance Date: 26.02.2022, DOI NO: 10.7456/11202100/017

Research Article - This article was checked by iThenticate Copyright (C) The Turkish Online Journal of Design, Art and Communication 
Interbrand (2021). Best Global Brands 2021, The Decade of Possibility. https:/www.rankingthebrands.com/PDF/Interbrand\%20Best\%20Global\%20Brands\%202021.pdf. Access Date: 14.02.2022.

Kantar Brandz (2021). 2021 Global Brands.

https://www.rankingthebrands.com/PDF/Brandz\%20Most\%20Valuable\%20Global\%20Brands\%20202 1,\%20Kantar.pdf. Access Date: 14.02.2022.

Kantar Worldpanel (2017). Brand footprint, a global ranking of the most chosen consumer brands. Issue 5, May 2017.

Kantar Worldpanel (2020). Brand footprint, a global ranking of the most chosen consumer brands. Issue 8, May 2020.

Kathuria, A. (2016). Social media content analysis. International Journal of Recent Trends in Engineering and Research (IJRTER), 02(09): 228-230.

Keller, K. L. (2001). Mastering the marketing communications mix: Micro and macro perspectives on integrated marketing communication programs. Journal of Marketing Management, 17: 819-847.

Kim, J. Y. and Hammick, J. K. (2013). Corporate communication on Twitter: Relationship effects on audience behavior. PRism, 9(1). https://www.prismjournal.org/uploads/1/2/5/6/125661607/v9-no1a9.pdf. Access Date: 12.10.2016.

Kwok, L. and Yu, B. (2012). Spreading social media messages on Facebook: An analysis of restaurant Business-to-Consumer communications. Cornell Hospitality Quarterly, XX(X): 1-11.

Lai, L. S. and To, W. T. (2015). Content analysis of social media: A grounded theory approach. Journal of Electronic Commerce Research, 16(2): 138-152.

Lalicic, L., Huertas, A., Moreno, A. and Jabreel, M. (2020). Emotional brand communication on Facebook and Twitter: Are DMOs successful?. Journal of Destination Marketing \& Management, 16, 1-11.

Macnamara, J. (2005). Media content analysis: Its uses; benefits and best practice methodology. Asia Pacific Public Relations Journal, 6(1): 1-34.

Mangold, W. G. and Faulds, D. J. (2009). Social media: The new hybrid element of the promotion mix. Business Horizons, 52: 357-365.

Neti, S. (2011). Social media and its role in marketing. International Journal of Enterprise Computing and Business Systems, 1(2): 1-14.

Özsomer, A., Batra, R., Chattopadhyay, A. and ter Hofstede, F. (2012). A global brand management roadmap. International Journal of Research in Marketing, 29(1): 1-4.

Paquette, H. (2013). Social media as a marketing tool: A Literature Review. University of Rhode Island DigitalCommons@URI, Major Papers by Master of Science Students.

https://digitalcommons.uri.edu/cgi/viewcontent.cgi?article=1001andcontext=tmd_major_papers. Access Date: 15.10.2016.

Parsons, A. (2013). Using social media to reach consumers: A content analysis of official Facebook pages. Academy of Marketing Studies Journal, 17(2): 27-36.

Rahman, Z., Suberamanian, K. and Zanuddin, H. B. (2016). Social media content analysis - A study on fanpages of electronics companies. International Journal on Global Business Management and Research, 5(1): 87-96.

Research Article - This article was checked by iThenticate Copyright (C) The Turkish Online Journal of Design, Art and Communication 
Rahman, Z., Suberamanian, K., Zanuddin, H. and Md Nasir, M. H. N. (2017). Social media content analysis "Study on brand posts of electronic companies"'. Journal of Engineering and Applied Sciences, 12(1): 87-94.

Reuben, R. (2008). The Use of Social Media in Higher Education for Marketing and Communications: A Guide for Professionals in Higher Education".

http://citeseerx.ist.psu.edu/viewdoc/download?doi=10.1.1.534.79andrep=rep1andtype=pdf. Access Date: 18.10 .2016$.

Richards, D. R. and Friess, D. A. (2015). A rapid indicator of cultural ecosystem service usage at a fine spatial scale: Content analysis of social media photographs. Ecological Indicators, 53: 187-195.

Schwartz, H. A. and Ungar, L. H. (2015). Data-driven content analysis of social media: A systematic overview of automated methods. The Annals of the American Academy of Political and Social Science, 659: 78-94.

Shen, B. and Bissell, K. (2013). Social media, social me: A content analysis of beauty companies' use of Facebook in marketing and branding. Journal of Promotion Management, 19: 629-651.

Social Brands, Facebook (2022). (https://www.boomsocial.com/Social-

Brands/2022/Subat/Facebook/hizli-tuketim/icecek). Access Date: 09.02.2022.

Social Brands, Twitter (2022). (https://www.boomsocial.com/Social-Brands/2022/Subat/Twitter/hizlituketim/icecek). Access Date: 09.02.2022.

Taecharungroj, V. (2016). Starbucks' marketing communications strategy on Twitter. Journal of Marketing Communications, 23(6): 552-571.

Taylor, M. and Kent, M. L. (2010). Anticipatory socialization in the use of social media in public relations: A content analysis of PRSA's Public Relations Tactics. Public Relations Review, 36: 207214.

Thomas, S., Bestman, A., Pitt, H., Deans, E., Randle, M., Stoneham, M. and Daube, M. (2015). The marketing of wagering on social media: An analysis of promotional content on YouTube, Twitter and Facebook, Victoria, Australia: Victorian Responsible Gambling Foundation.

https://ro.uow.edu.au/cgi/viewcontent.cgi?article=1694andcontext=ahsri. Access Date: 13.11.2016.

Ungerman, O. (2015). Social media as a marketing communication tool used by family firms. https://pdfs.semanticscholar.org/b5e6/6676flc00b33e2186f0f1 fad15483584bd73.pdf. Access Date: 11.10.2016.

Waters, R. D. and Lo, K. D. (2012). Exploring the impact of culture in the social media sphere: A content analysis of Nonprofit Organizations' Use of Facebook". Journal of Intercultural Communication Research, 41(3): 297-319.

Wirga, E. W., Natalisa, D., Wiryana, I. M. and Natalisa, D. (2012), Social media content analysis for marketing strategy. Proceedings of the 3rd Uzbekistan-Indonesia international joint conference on economic development and nation character building to meet the global economic challenges (pp. 198203).

http://repository.gunadarma.ac.id/907/1/SOCIAL\%20MEDIA\%20CONTENT\%20ANALYSIS\%20FO R\%20MARKETING\%20STRATEGY_UG.pdf. Access Date: 11.10.2016. 